\title{
Institutional change and the development of lagging regions in Europe
}

\author{
Andrés Rodríguez-Pose ${ }^{1}$ and Tobias Ketterer ${ }^{2}$
}

\footnotetext{
${ }^{1}$ Department of Geography and Environment, London School of Economics (a.rodriguez-pose@1se.ac.uk)

${ }^{2}$ DG EcFin, European Commission (Tobias.KETTERER@ec.europa.eu)
} 


\title{
Institutional change and the development of lagging regions in Europe
}

\begin{abstract}
In this paper we assess whether both the levels and the degree of change in government quality influence regional economic performance in the European Union (EU) and, in particular, in its lagging regions. The results of the econometric analysis, covering 249 NUTS2 regions for the period between 1999 and 2013, suggest that: a) government quality matters for regional growth; b) relative improvements in quality of government are a powerful driver of development; c) one-size-fits-all policies for lagging regions are not the solution; d) government quality improvements are essential for low growth regions; and e) in low income regions basic endowment shortages are still the main barrier to development. In particular, low growth regions in Southern Europe stand to benefit the most from improvements in government quality, while in low income regions of Central and Eastern Europe, investments in the traditional drivers of growth remain the main factors behind successful economic trajectories.
\end{abstract}

Keywords: Economic growth, government quality, institutional change, regions, EU

JEL Classification: R11, R50. 


\section{Introduction}

According to the dominant economic theories, economic growth is the result of a combination of three factors - physical capital, human capital or labour, and innovation - plus a residual factor or error term, which represents what we do not know or cannot explain. Depending on whether a neoclassical growth (Solow, 1956; Swan, 1956) or an endogenous growth approach is adopted (Romer, 1986: Lucas, 1988), the weight attributed to each of the components varies, but they remain the fundamental drivers informing development policies across the world. The European Union's (EU) regional development and cohesion policy has been no exception. The bulk of cohesion investments have been channelled towards improving the infrastructure endowment and accessibility of the least developed regions of the EU, as well as increasing the availability and quality of human resources, and developing the innovative capacity of individuals and firms across lagging-behind areas of Europe.

By and large, this sort of intervention has borne fruit, as the performance of lagging regions of Europe has outstripped that of the core in recent years (Becker et al., 2010; Pellegrini et al., 2013). However, the success of the policy in delivering greater economic convergence does not hide the fact that we are witnessing a decline in the returns of intervention in the three main growth axes. There is, for example, growing concern about a potential exhaustion of additional investments in transport infrastructure and of improvements in accessibility as drivers of growth in certain lagging regions of Europe (Crescenzi and Rodríguez-Pose, 2012). While this issue remains controversial, the truth is that physical capital, human capital, and technology explain a waning share of the variation in regional economic growth in Europe. Growth theories that accounted for differences in economic performance relatively well two decades ago are becoming less capable of doing so. The residual factor is growing, meaning that, in spite of improvements in growth theory, we tend to know less about what determines regional growth in Europe.

This declining explanatory capacity signals that a key factor in the growth equation has been missing. Most eyes have turned to the role of institutions, in general, and government quality, in particular (Charron et al., 2013). However, measuring 
institutional quality, especially at the regional level, has been difficult and fraught with controversy (Rodríguez-Pose, 2013). Despite these problems, strides have been made of late in assessing government quality at a regional level in Europe. The biggest breakthrough was by the Quality of Government Institute of the University of Gothenburg, which has produced a subjective quality of government (QoG) index (Charron et al., 2011, 2014a, and 2014b). Numerous studies have turned to the QoG in order to explain how regional variations in quality of government contribute to shape the economic dynamism of regions in Europe. The large majority of these studies has reached the conclusion that government quality matters for economic performance and that poor government in lagging areas of Europe represents a significant barrier to development. Government quality not only affects economic growth, but also the returns of European cohesion policies (Rodríguez-Pose and Garcilazo, 2015), shapes regional competitiveness (Annoni and Dijkstra, 2013). Moreover, corrupt and/or inefficient governments undermine regional potential for innovation (Rodríguez-Pose and Di Cataldo, 2015) and entrepreneurship (Nistotskaya et al., 2015) and weaken the attractiveness of regions to migrants (Ketterer and Rodríguez-Pose, 2015). Regional environmental performance (Halkos et al., 2015) and decisions on the type of public good investment (Crescenzi et al., 2016) are also affected, as well as the inclusiveness and participation in political processes (Sundström and Wängnerud, 2014).

These studies represent substantial progress in our understanding of the role of government quality as a shaper of regional growth in lagging areas of Europe, but are limited in two respects. First, they consider institutional conditions as a factor affecting economic development. Regions have a better or worse endowment of institutions, depending, among other factors, on their history (Charron and Lapuente, 2013) and quality of government operates in a path dependent way. This perception of institutions often implies that government quality remains more or less stable over time, as a permanent barrier/enabler to/of economic development. Yet, while institutional conditions do persist in time, they also change and, sometimes, change rapidly. Estonia, for example, has become in the space of two decades one of the world leaders in the use of e-government, greatly improving the overall efficacy, accountability and transparency of government. Latvia, by contrast and despite sharing many historical traits with Estonia and a comparable starting point, has been unable to undertake similar levels of institutional transformation. This potential for institutional change has, 
nevertheless, been overlooked by the literature, limiting our understanding of how change in government quality impacts on economic development.

Second, because of data constraints, most of the above-mentioned analyses on government quality have considered a period covering exclusively the boom that preceded the 2008 economic crisis. Hence, we know how government quality affects economic performance in a period of economic expansion, but we know next to nothing about whether the quality of government has a similar effect on regional economic performance in periods of deep recession, such as that of post-2008 Europe, or over changes in the economic cycle.

This paper addresses these gaps in our knowledge by assessing whether both the levels and the degree of change in government quality influence regional economic performance in the whole of Europe and, in particular, in lagging regions of the EU. We also analyse whether the effect of government quality - and that of the other more traditional factors included in growth theories - resists deep changes in the economic cycle, such as those experienced by the EU since 2008. In order to do so, we use Charron et al.'s (2011; 2014a) regional quality of government dataset in conjunction with indicators referring to endowments and investments in accessibility, education and training, and innovation. These data are gathered for a total of 249 NUTS2 regions in the EU for the period between 1999 and 2013. The aim is to discriminate between the role played by traditional areas in development policy intervention, such as infrastructure, human capital and innovation, from that of different government quality aspects, such as corruption, the rule of law, government effectiveness, and government accountability. Particular attention is paid to changes in all these factors, as well as to the importance of quality of government for the development of lagging regions of Europe. Another differentiating factor from previous studies is that lagging regions are not considered as a uniform mass, but are divided, following the European Commission (2014), into low income and low growth regions, based on the initial levels of development and the economic performance over the period of analysis.

The paper is structured as follows. In the next section the theoretical model is presented. Section 3 introduces the empirical approach and the data used in the analysis. Section 4 exposes the results of the econometric analysis, while section 5 discusses the role of 
government quality and place-sensitive policies for lagging regions in Europe in light of the empirical results. A reflection on the capacity to move to a next level of development for lagging-behind regions appears in the final section.

\section{The theoretical model}

The standard neoclassical Solow-Swan growth model with physical and human capital (Solow, 1956; Swan, 1956, Mankiw et al., 1992) has for decades informed development policies around the world. We use this model and approach as our benchmark investigation framework. In this simple model regional output is determined by the following production function:

$$
Y(t)=F[A(t), K(t), H(t), L(t)]
$$

where regional output (Y) is broadly the consequence of a technology parameter (A), regional physical capital $(\mathrm{K})$, regional human capital $(\mathrm{H})$, and the labour force $(\mathrm{L})$. We assume that technological and economic progress are affected by institutional parameters reflecting the quality, efficiency, accountability of governments, the relevance of corruption in a territory, and the state of the judicial system. From this perspective economic growth is constrained by government or social capability, meaning that the institutional environment contributes to determine why certain development strategies and types of public intervention take hold, and others do not. Institutional conditions, such as government quality, affect technical progress, the efficiency of investment, and, as a consequence, the responsiveness of output to human and physical capital (i.e. infrastructure, property rights, and education - which all tend to be sensitive to institutions). Institutional parameters may thus be sub-divided into elements focusing on human capital related components and local region-specific legal and governmental aspects (Acemoglu and Dell, 2009) both of which influence technical, as well as non-technical regional growth parameters.

Taking this into account, we define the technology parameter $\mathrm{A}($.$) as a combination of$ technological know-how - i.e. productive efficiency $\mathrm{T}($.$) , which again is determined by$ technology adaption choices of profit-maximising firms, and the presence or quality of local and national institutions, I(.), reflected in the provision of public goods and services, the availability of a functioning legal system, and the protection of property 
rights. We can therefore illustrate the technology parameter as a function $G[$.$] , of T($. and $\mathrm{I}($.$) :$

$$
A(t)=G[T(.), I(.)]
$$

We develop the traditional Solow-Swan growth framework considering both physical and human-capital aspects à la Mankiw et al. (1992), on the one hand, and institutional - government quality - regional parameters, on the other. We assume a simple linear relationship between $\mathrm{T}($.$) and \mathrm{I}($.$) and substitute equation (2) into equation (1). Using a$ constant-returns-to-scale Cobb-Douglas production function, the equation (1) is rewritten as follows:

$$
Y(t)=K^{\alpha}(t) H^{\beta}(t)[I(.) T(t) L(t)]^{1-\alpha-\beta}
$$

where I(.) denotes a matrix of institutional measures and T(.) a vector of company-based productive efficiency. We further assume that European regions differ in their initial technology level (i.e. in technological effectiveness or institutional background) and that the overall productive efficiency $\mathrm{T}($.$) is similar across all territories (Mankiw et al.,$ 1992). By computing steady-state values of human and physical capital per effective unit of labour (3) and taking natural logarithms, the following structural equation for a region's long-run income per capita levels can be derived (cf. Mankiw et al., 1992):

$$
\ln \left[\frac{\mathrm{Y}(\mathrm{t})}{\mathrm{L}(\mathrm{t})}\right]=\ln \mathrm{T}(0)+\mathrm{gt}+\ln \mathrm{I}(0)-\frac{\alpha+\beta}{1-\alpha-\beta} \ln \left(\mathrm{n}_{\mathrm{t}}+\mathrm{g}+\delta\right)+\frac{\alpha}{1-\alpha-\beta} \ln \left(\mathrm{s}_{\mathrm{k}}\right)+\frac{\beta}{1-\alpha-\beta} \ln \left(\mathrm{s}_{\mathrm{h}}\right)
$$

where $\mathrm{Y}(\mathrm{t}) / \mathrm{L}(\mathrm{t})$ denotes regional GDP per capita, $\mathrm{s}_{\mathrm{k}, \mathrm{t}}$ regional savings or investment, $\mathrm{s}_{\mathrm{h}, \mathrm{t}}$ human capital accumulation, $\mathrm{n}_{\mathrm{it}}$ regional population growth, $\mathrm{g}$ the exogenous technology growth rate, and $\delta$ the rate of depreciation. The model predicts higher real income in territories with higher savings- (i.e. investment-) rates, a higher level of innovative capacity, technological progress, and better institutional conditions.

\section{Empirical approach}

\subsection{Estimation strategy and econometric specification}


The empirical methodology is based on the extended neoclassical Solow-Swan-type estimation model presented in the previous section, distinguishing between different indicators of a region's physical accessibility, human-capital and innovation-related regional factors, as well as between several different measures of a region's government quality.

To control for potentially omitted variables and reduce endogeneity concerns, due to reverse causality or simultaneity, we introduce all independent variables with a fiveyear lag. The use of a five-year lag responds to the expectations that the types of capital investment associated with regional development policies, in general, and European Cohesion policies, in particular - improvements in accessibility, education and training, and science and technology investments - are likely to leave a long-lasting impact which goes well beyond short-term Keynesian-type multiplier effects. Government quality also shows a large degree of persistence and path dependence (Charron and Lapuente, 2013; Charron et al., 2014). In addition, we provide further empirical results by resorting to a heteroscedasticity-robust system 'Generalized Method of Moments' (GMM) estimator (Roodman, 2009) which, in theory, addresses potential endogeneity issues.

The empirical model accounts for physical and human capital, as well as for different levels of innovative capacity and regional institutional quality. It adopts the following form:

$$
\begin{aligned}
& \ln \left(\mathrm{y}_{\mathrm{i}, \mathrm{t}}\right)-\ln \left(\mathrm{y}_{\mathrm{i}, \mathrm{t}-1}\right)=\beta_{0}+\beta_{1} \ln \left(\mathrm{y}_{\mathrm{i}, \mathrm{t}-5}\right)+ \\
& \beta_{2} \ln \left(\text { investment }_{\mathrm{i}, \mathrm{t}-5}\right)+\beta_{3} \ln \left(\text { human_captial }_{\mathrm{i}, \mathrm{t}-5}\right)+\beta_{4} \ln \left(\text { institution }_{\mathrm{i}, \mathrm{t}-5}\right)+ \\
& \beta_{5} \ln \left(\mathrm{n}_{\mathrm{i}, \mathrm{t}-5}+\mathrm{g}+\delta\right)+\mathrm{y}_{\mathrm{i}}+\mathrm{v}_{\mathrm{t}}+\varepsilon_{\mathrm{i}, \mathrm{t}}
\end{aligned}
$$

where the index i represents the region with i e $[1,249]$ and $t$ denotes a time index in a sample covering the period 1999-2013. Real GDP per capita (in PPS) of NUTS-2 region $\mathrm{i}$ at time $\mathrm{t}$ is denoted by $\mathrm{y}_{\mathrm{i}, \mathrm{t}}$. Regional physical capital (i.e. investment $\mathrm{t}_{\mathrm{i}, \mathrm{t}-1}$ ) is measured by the level of gross fixed capital formation (in $\%$ of nominal GDP). We further decompose the investment variable into a more general indicator of a region's physical capital stock and into an additional parameter accounting for regional accessibility. 
The human capital parameter (human_capital $\mathrm{i}_{\mathrm{i}, \mathrm{t}-1}$ ) represents regional education levels, proxied by the share of people in employment with tertiary education. $\mathrm{n}_{\mathrm{i}, \mathrm{t}-1}$ denotes population growth rate in the region, while $g$ and $\delta$ reflect technological progress and capital depreciation, which we assume to be constant over time and to jointly add up to a value of 5\% (cf. Mankiw et al., 1992).

Institutions at a regional level and their change are proxied by Charron's et al. (2011; $2014 \mathrm{a}$; 2014b) index of regional quality of government. ${ }^{1}$ The regional government quality index is decomposed into its four constituent components which include (i) corruption, (ii) rule of law, (iii) government effectiveness and bureaucracy, and (iv) government accountability. The empirical model (5) has regional fixed effects $\left(\mathrm{V}_{\mathrm{i}}\right)$ and annual time fixed effects $\left(v_{t}\right)$ as a means to control for regional or time-specific characteristics. $\varepsilon_{\mathrm{i}, \mathrm{t}}$ represents the idiosyncratic error term.

The estimated standard growth model of equation (5) is further extended by including the level and changes of innovation, education and investment-related indices, combining several potential economic growth indicators by means of principal component analysis. Principal component analysis can be used to account for potential multicollinearity issues when simultaneously introducing certain potentially correlated explanatory variables. ${ }^{2}$ Different regressors are merged into one composite index, allowing us to preserve "as much as possible of the variability of the original indicators" (Crescenzi and Rodríguez-Pose, 2012: 57). The resulting augmented Solow-Swan-type growth model adopts the following form:

\footnotetext{
${ }^{1}$ Data availability limits the analysis to the use of mostly formal institutions - although corruption levels are also included - of government quality. Another interesting strand of research would be to consider the role played by informal institutions, such as social capital, trust or shared values (see, for instance, the work of Beugelsdijk and Van Schaik, 2005 or Akçomak and Ter Weel 2009). This, however, would goes beyond the scope of the paper and would require a separate analysis.

${ }^{2}$ Potential drawbacks of principal component analysis include relying on linear assumptions and on orthogonal transformations, as well as issues linked to the use of variance to determine the influence of a particular dimension.
} 


$$
\begin{aligned}
& \ln \left(\mathrm{y}_{\mathrm{i}, \mathrm{t}}\right)-\ln \left(\mathrm{y}_{\mathrm{i}, \mathrm{t}-1}\right)=\beta_{0}+\beta_{1} \ln \left(\mathrm{y}_{\mathrm{i}, \mathrm{t}-5}\right)+ \\
& \beta_{2} \ln (\text { investment })_{\mathrm{i}, \mathrm{t}-5}+\beta_{3} \ln \left(\text { accessibility index)_level and growth }_{\mathrm{i}, \mathrm{t}-5}+\right. \\
& \beta_{3} \ln (\text { human capital and innovation index)_level and growth } \\
& \beta_{4, \mathrm{t}-5}+ \\
& \beta_{4} \ln \text { (institutions)_level and growth } \mathrm{i}_{\mathrm{i}, \mathrm{t}-5}+\beta_{5} \ln \left(\mathrm{n}_{\mathrm{i}, \mathrm{t}-5}+\mathrm{g}+\delta\right)+\mathrm{y}_{\mathrm{i}}+\mathrm{v}_{\mathrm{t}}+\varepsilon_{\mathrm{i}, \mathrm{t}}
\end{aligned}
$$

where all parameters are defined as above and the three composite indices account for the stock and improvements in regional accessibility, as well as for the level and change in educational and innovation-related regional attributes. The accessibility index is built combining road network data, measuring potential road accessibility as the inverse time-distance weighted population ${ }^{3}$ with the ratio of air transport passengers over regional population, using principal component analysis.

In order to benchmark the determinants of economic growth in lagging regions relative to the drivers of growth in the EU as a whole, we estimate growth models for the EU as a whole, as well as for different types of lagging regions - low growth and low income. The distinction between low growth and low income regions was established by the European Commission in the $6^{\text {th }}$ Cohesion Report (2014). In it, for the first time, the considerable heterogeneity of lagging-behind regions in Europe was brought to the fore. In particular, the different trajectories of regions in the economic periphery of Europe that, despite remaining very poor, had grown over the period between 2000 and 2013 well above the European average (low income regions) and those that, although starting from a higher level of development, had failed to converge (low growth regions) (Figure 1).

Figure 1. Low income and low growth regions in Europe.

\footnotetext{
${ }^{3}$ The road accessibility data are based on road network data for the years 2001, 2006, 2011 and 2014, with the remaining years being extrapolated or interpolated. The raw data were gathered by Klaus Spiekermann and provided by Lewis Dijkstra in the European Commission. The distance decay function is a fairly steep exponential function that becomes close to zero after four hours of travel.
} 


\section{Lagging Regions}

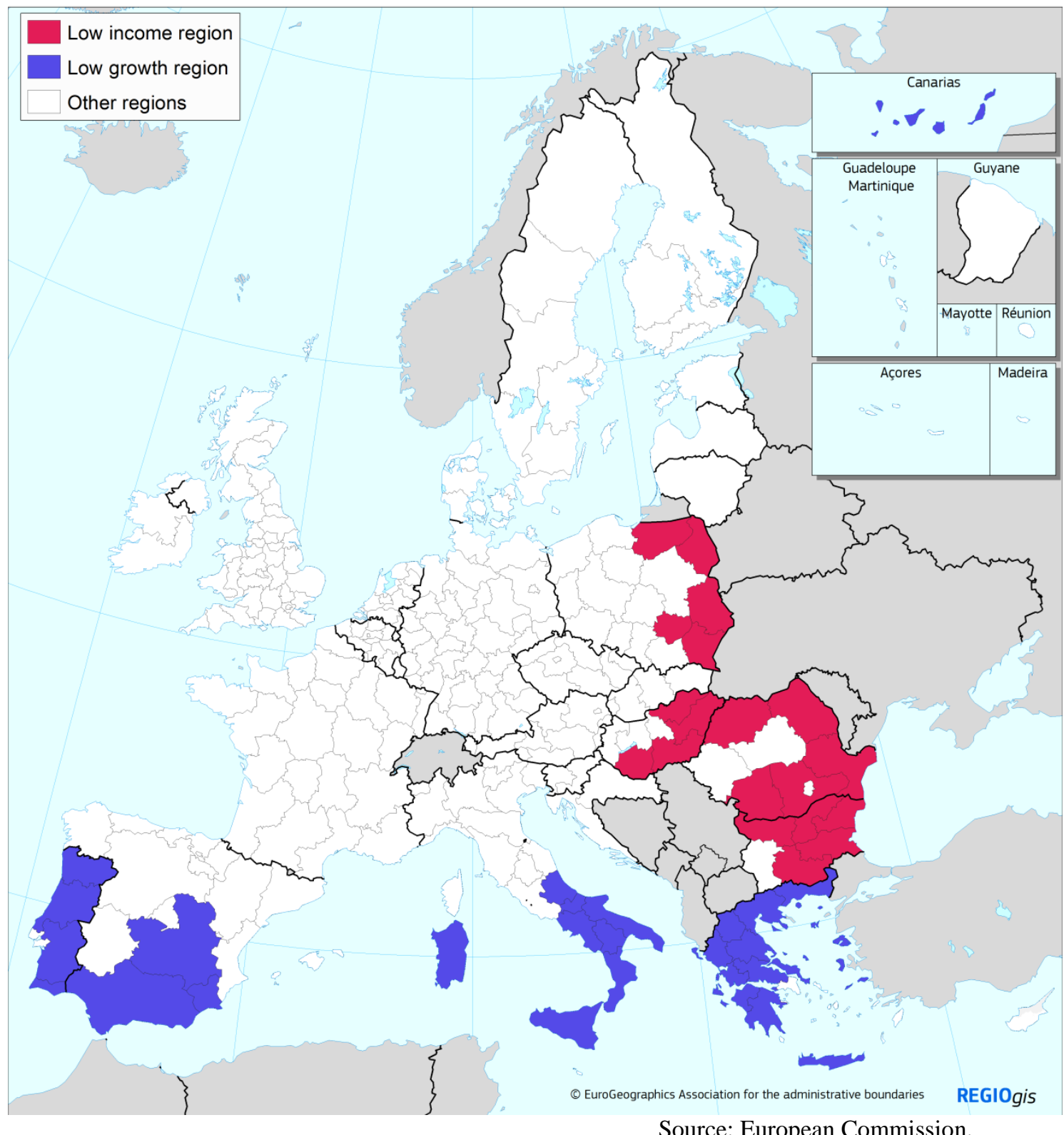

Source: European Commission.

\subsection{Data}

The exact definitions of the variables introduced and data sources used in the empirical analysis are summarized in Table A1 in the Annex. The descriptive statistics and correlation matrix are presented in Tables A2a and A2b, while Table A3 contains the correlation and eigenvector results of the principal component analysis. The aim of this section is to highlight some of the most important characteristics of the dataset. The analysis is based on regional NUTS-2 level ${ }^{4}$ data covering the whole of the EU during

\footnotetext{
${ }^{4}$ Nomenclature of Territorial Unit for Statistics (NUTS) as defined by the European Commission.
} 
the period between 1995 and 20013 (1995-2009 for the independent variables, 19992013 for the dependent variable: regional economic growth). For countries without regional subdivisions at NUTS-2 level (Estonia, Latvia, Lithuania, and Luxembourg) country-wide statistics were used. Data for a total of 256 regions in 24 EU countries was gathered. Some individual regions and countries were excluded due inadequate data availability or as a consequence of recent changes in NUTS-2 boundaries. ${ }^{5}$ This left a dataset with complete data for a total of 249 regions. With the exception of the government quality parameters, the source for all variables is Eurostat's Regio database.

The government quality variables stem from Charron et al.'s (2014a) quality of government (QoG) index. This index is constructed by combining the World Bank's country-level 'World Governance Indicators' (WGI) (Kaufmann et al., 2009) with an EU-wide regional survey based on approximately 34,000 EU citizens. ${ }^{6}$ The survey includes 16 questions aimed at evaluating the citizens' experience and perception of the local institutional quality (Charron et al., 2011). The questions focus on three general public services that are administered or financed in a considerable number of countries at a regional (i.e. sub-national) level: education, health care, and law enforcement. Rating these services with respect to their quality, impartiality, and the presence of corruption, the respondents assigned different scores to each of the 16 questions. The responses were then aggregated from the individual to the regional level and also to the national level. The 16 regional scores were classified into four subgroups identifying citizens' perception of (i) the prevalence of corruption, (ii) the rule of law, (iii) regional government, and (iv) the strength of democracy and electoral institutions (voice and accountability). The scores were standardized and the regional value subtracted from the national score. This provided a regional distance to the national score in standard deviations. The regional distance was subsequently standardised at the EU level using

\footnotetext{
5 Croatia, Cyprus, Denmark, and Malta had to be excluded from the analysis due to missing data. Additionally, some individual regions were not included in the analysis for the same reasons. These comprise Ceuta and Melilla, all French overseas departments (Guadeloupe, Martinique, Guyane, Réunion), Açores and Madeira, and North Eastern Scotland and the Highlands and Islands. Recent changes in NUTS-2 boundaries led to the exclusion of the Finnish regions of Helsinki-Uusimaa, EteläSuomi, Pohjois-Suomi, and Itä-Suomi.

${ }^{6}$ The survey - one of the largest ever conducted at a regional (i.e. subnational) level - is based on around 200 participants per region and consisted of 34 quality of government-, and demography-related questions, amongst others on education, health care, and law enforcement. For more detailed information on the survey as well as the construction of the indices see Charron et al. (2011 and 2014a).
} 
the World Bank Worldwide Governance Indicators (WGI) time series. Finally, all four individual components were merged into a composite measure of quality of government: the quality of government index (QoG). A series of robustness tests were conducted by Charron et al. (2014a), showing that the quality of government index is highly robust to changes in weighting and aggregation, as well as to the social and agerelated composition of the survey respondents.

\section{Estimation of results}

\subsection{Results for the whole of the EU}

Table 1 presents the fixed effects estimations for the 249 EU regions included in the analysis, highlighting the decomposition of the quality of government index into its four main constituents: corruption (regression 2), rule of law (regression 3), government effectiveness (regression 4), and government accountability (regression 5).

The results of the analysis underline that some of the factors that explain change in regional economic growth in Europe over the last two decades are in line with the predictions of the neoclassical growth theory. The negative and highly significant coefficient of the initial GDP per capita indicator points to a considerable regional catch-up between 1999 and 2013. Although the crisis has hit the low growth income regions of southern Europe particularly hard, their divergence since 2008 has been more than compensated by a faster growth in the economic periphery than in the core between 1999 and 2008 and by the relatively resilient performance of many of the low income regions of Central and Eastern Europe since the inception of the crisis (Cuadrado-Roura et al., 2016). Lagged regional population growth rates are also negatively and significantly connected to economic per capita growth. 
Table 1. The drivers of growth - levels and change - at a regional level in the EU (1999-2013). Fixed effects estimation.

\begin{tabular}{|c|c|c|c|c|c|}
\hline \multirow[b]{2}{*}{ Variables } & \multicolumn{5}{|c|}{ Fixed effects analysis } \\
\hline & (1) & (2) & (3) & (4) & (5) \\
\hline Initial GDP per capita & $\begin{array}{r}-0.107 * * * \\
(0.011)\end{array}$ & $\begin{array}{r}-0.110 * * * \\
(0.010)\end{array}$ & $\begin{array}{r}-0.104 * * * \\
(0.011)\end{array}$ & $\begin{array}{r}-0.106 * * * \\
(0.011)\end{array}$ & $\begin{array}{r}-0.103 * * * \\
(0.011)\end{array}$ \\
\hline Investment & $\begin{array}{r}-0.016 * * * \\
(0.006)\end{array}$ & $\begin{array}{r}-0.016 * * * \\
(0.005)\end{array}$ & $\begin{array}{r}-0.016 * * \\
(0.006)\end{array}$ & $\begin{array}{r}-0.015^{* *} \\
(0.006)\end{array}$ & $\begin{array}{r}-0.016^{* * *} \\
(0.006)\end{array}$ \\
\hline Population growth & $\begin{array}{c}-0.308^{*} \\
(0.165)\end{array}$ & $\begin{array}{r}-0.328 * * \\
(0.159)\end{array}$ & $\begin{array}{c}-0.296^{*} \\
(0.163)\end{array}$ & $\begin{array}{r}-0.262 \\
(0.164)\end{array}$ & $\begin{array}{r}-0.344 * * \\
(0.164)\end{array}$ \\
\hline Agglomeration & $\begin{array}{r}0.003 \\
(0.016)\end{array}$ & $\begin{array}{r}0.003 \\
(0.015)\end{array}$ & $\begin{array}{r}0.001 \\
(0.016)\end{array}$ & $\begin{array}{r}0.003 \\
(0.016)\end{array}$ & $\begin{array}{r}0.005 \\
(0.016)\end{array}$ \\
\hline Level of accessibility index & $\begin{array}{r}-0.105^{* * *} \\
(0.027)\end{array}$ & $\begin{array}{r}-0.105^{* * * *} \\
(0.026)\end{array}$ & $\begin{array}{r}-0.109 * * * \\
(0.027)\end{array}$ & $\begin{array}{r}-0.108 * * * \\
(0.028)\end{array}$ & $\begin{array}{r}-0.100 * * * \\
(0.027)\end{array}$ \\
\hline Change of accessibility index & $\begin{array}{r}-0.151 \\
(0.093)\end{array}$ & $\begin{array}{r}-0.120 \\
(0.091)\end{array}$ & $\begin{array}{r}-0.099 \\
(0.091)\end{array}$ & $\begin{array}{r}-0.149 \\
(0.091)\end{array}$ & $\begin{array}{l}-0.151 \\
(0.094)\end{array}$ \\
\hline Level of human capital \& innovation index & $\begin{array}{r}0.008 \\
(0.011)\end{array}$ & $\begin{array}{r}0.007 \\
(0.011)\end{array}$ & $\begin{array}{r}0.012 \\
(0.011)\end{array}$ & $\begin{array}{r}0.010 \\
(0.010)\end{array}$ & $\begin{array}{r}0.011 \\
(0.011)\end{array}$ \\
\hline Change of human capital \& innovation index & $\begin{array}{c}-0.024 * \\
(0.012)\end{array}$ & $\begin{array}{r}-0.023 * \\
(0.012)\end{array}$ & $\begin{array}{r}-0.023 * \\
(0.013)\end{array}$ & $\begin{array}{r}-0.027 * * \\
(0.013)\end{array}$ & $\begin{array}{r}-0.022 * \\
(0.012)\end{array}$ \\
\hline Level of institutional quality (QoG) & $\begin{array}{r}0.007 \\
(0.062)\end{array}$ & & & & \\
\hline Change of institutional quality (QoG) & $\begin{array}{r}0.227 * * \\
(0.088)\end{array}$ & & & & \\
\hline Institutional index components & & & & & \\
\hline Level of corruption index & & $\begin{array}{r}-0.021 \\
(0.053)\end{array}$ & & & \\
\hline Change of corruption index & & $\begin{array}{r}0.195 * * * \\
(0.053)\end{array}$ & & & \\
\hline Level of rule of law index & & & $\begin{array}{r}0.030 \\
(0.046)\end{array}$ & & \\
\hline Change of rule of law index & & & $\begin{array}{r}-0.310^{* * * *} \\
(0.081)\end{array}$ & & \\
\hline Level of government effectiveness & & & & $\begin{array}{r}0.002 \\
(0.038)\end{array}$ & \\
\hline Change of government effectiveness & & & & $\begin{array}{r}0.158 * * * \\
(0.038)\end{array}$ & \\
\hline Level of government accountability & & & & & $\begin{array}{r}0.056 \\
(0.035)\end{array}$ \\
\hline Change of government accountability & & & & & $\begin{array}{l}0.059 * \\
(0.032)\end{array}$ \\
\hline Constant & $\begin{array}{r}2.399 * * * \\
(0.431)\end{array}$ & $\begin{array}{r}2.505 * * * \\
(0.443)\end{array}$ & $\begin{array}{r}2.396 * * * \\
(0.428)\end{array}$ & $\begin{array}{r}2.444 * * * \\
(0.432)\end{array}$ & $\begin{array}{r}2.138 * * * \\
(0.444)\end{array}$ \\
\hline Observations & 2,802 & 2,802 & 2,802 & 2,801 & 2,802 \\
\hline Number of regions & 249 & 249 & 249 & 249 & 249 \\
\hline Time FE & YES & YES & YES & YES & YES \\
\hline $\mathrm{R}^{2}$ within & 0.555 & 0.556 & 0.560 & 0.556 & 0.556 \\
\hline $\mathrm{R}^{2}$ between & 0.0917 & 0.0946 & 0.0773 & 0.0884 & 0.0862 \\
\hline $\mathrm{R}^{2}$ overall & 0.0846 & 0.0833 & 0.0779 & 0.0817 & 0.0912 \\
\hline
\end{tabular}

Notes: $* * *, * * *$ illustrate significance at $10 \%, 5 \%$, and $1 \%$, respectively. The standard errors are listed in parentheses. Investment is proxied by regional gross fixed capital formation as a percentage of GDP. All independent variables are included with a five year lag. Natural logarithms have been taken for most regressors apart from the population growth variable. All regressions include constant time dummies. 
The more interesting results relate, however, to the factors that are traditionally most consistently associated with economic dynamism. Neither levels of investment, nor the accessibility of a region display any positive association with regional economic growth in Europe. Productive capital stock investments have a negative and significant coefficient (Table 1). The coefficient for road accessibility is also negative and strongly significant. Hence, a good accessibility - the aim of a considerable proportion of the European Cohesion effort until now - has not contributed to a noticeable rise in economic growth in recent years. The coefficient for the level of human capital and innovation is insignificant, as is that of the government quality indicator, the independent variable of interest (Table 1). This result contrasts with previous studies using pre/crisis data (Nistotskaya et al., 2015; Rodríguez-Pose and Garcilazo, 2015; Rodríguez-Pose and Di Cataldo, 2015) and implies that, when considering a period of time that involves pre-and post-crisis performance, regional quality of government may have less of an influence on economic outcomes. Hence, in a period dominated by a radical alteration in regional growth patterns following the inception of the crisis, better or worse regional endowments in the factors that, according to standard economic theory, are likely to have a greater sway of regional growth, do not seem to have played an important role in determining regional growth trajectories (Table 1).

Does this also apply to changes in these factors? Have improvements in accessibility, human capital and innovation, and government quality made a difference for the performance of European regions during the period of analysis? The coefficients for improvements in accessibility - which may require a longer timeframe than that afforded by the analysis to be properly assessed - show no significant connection to economic growth. Increases in the human capital and innovation effort are, by contrast, negatively and significantly related to economic growth (Table 1). Given these results, changes in the three fundamental growth theory factors do not seem to have shaped regional economic performance in a Europe characterised by a strong boom and bust cycle.

This does not apply, however, for changes in the regional quality of government. The coefficient for change in the composite government quality index is positive and significant at the $1 \%$ level (Table 1, regression 1). Similarly, improvements in three of the four dimensions of regional government quality - control of corruption, government 
effectiveness, and accountability - are positively and significantly associated with economic growth (Table 1, regressions 2, 4, 5). Improvements in the rule of law, in contrast, show a negative and significant connection with regional growth. It can therefore be inferred that a weak government quality has not represented a significant barrier for economic growth during the period of analysis. All coefficients for the variables depicting the levels of government quality are insignificant (Table 3, regression 2). By contrast, reducing corruption and improving government effectiveness and accountability have been crucial in determining which regions have performed better and which worse in recent years.

These results for the quality of government variables are confirmed when the method of estimation is changed. Table A4 in the Annex presents the same analysis as in Table 1 using heteroscedasticity-robust System-GMM estimation techniques in all regressions. ${ }^{7}$ A system-GMM dynamic panel data estimation was used not only as a robustness check of the results of the fixed effects analyses, but also to control for potential endogeneity.

\subsection{Lagging regions in the $\mathrm{EU}$}

The previous analysis has looked at the role played by quality of government and the traditional factors behind economic growth (according to theory) in determining the economic performance of European regions between 1999 and 2013. But what happens when we focus exclusively on lagging regions? Do lagging regions benefit in the same way as the average European region from change in quality of government? Tables 2 and 3 present the results of applying model (6) to the two subsets of less-developed regions identified by the European Commission (2014): the low growth regions of southern Europe and the low income regions of Eastern Europe.

\subsubsection{Low growth regions}

The results indicate that in low growth regions, the 2000s and early 2010s have been characterised by territorial convergence within the group. Greater investment has been associated with lower levels of growth, while the population growth rate is disconnected

\footnotetext{
${ }^{7}$ All independent variables were classified as endogenous in all regressions and the fourth and third lag were employed as (internal) instruments for the endogenous variables.
} 
from economic performance. Population agglomeration, by contrast, has been a strong factor behind the economic dynamism of these areas. A good initial accessibility as well as improvements in accessibility - on which the EU has invested the bulk of its Cohesion funds in these regions - have been more often than not a drag for their performance, as virtually all the coefficients are negative and significant (Table 2, regressions 1. 2, 4, and 5). And while progress in human capital and innovation are not associated to regional economic growth, initial endowments in this index have been essential for good economic performance in this subset of lagging-behind regions.

There are also important changes concerning government quality. Seven of the ten government quality variables - level of corruption, change in the rule of law and the degree of government accountability being the exceptions - are statistically significant, denoting the important role played by this type of institution in shaping recent economic performance in the lagging regions of southern Europe. The sign of the coefficients also indicates that a poor quality of government has not necessarily been an insurmountable barrier for the economic performance of these regions. Regions with a weaker government quality, and, in particular, those with a less efficient judicial system and less effective governments have outperformed those with better initial levels of institutional quality (Table 1, regressions 1, 2, 3, and 4). Relative improvements in government quality have also been fundamental channels to increase economic performance. Regions which have experienced the greatest advances in overall quality of government and, specifically, in reducing corruption and increasing government effectiveness and accountability have had a better economic trajectory. Those that, by contrast, have seen a deterioration of their institutional quality - as in the case of most of Italy or northern France - have witnessed a rise of discontent and frustration with local institutions which, at times, has been translated into an increase in votes for antisystem and populist parties (Rodríguez-Pose, 2018). 
Table 2. The drivers of growth - levels and change - in low growth regions of the EU (1999-2013). Fixed effects estimation.

\begin{tabular}{|c|c|c|c|c|c|}
\hline \multirow[b]{2}{*}{ Variables } & \multicolumn{5}{|c|}{ Fixed effects analysis } \\
\hline & (1) & (2) & (3) & (4) & (5) \\
\hline Initial GDP per capita & $\begin{array}{r}-0.224 * * * \\
(0.038)\end{array}$ & $\begin{array}{r}-0.218 * * * \\
(0.039)\end{array}$ & $\begin{array}{r}-0.276 * * * \\
(0.044)\end{array}$ & $\begin{array}{r}-0.259 * * * \\
(0.045)\end{array}$ & $\begin{array}{r}-0.179 * * * \\
(0.039)\end{array}$ \\
\hline Investment & $\begin{array}{r}-0.037 * * \\
(0.017)\end{array}$ & $\begin{array}{c}-0.029^{*} \\
(0.015)\end{array}$ & $\begin{array}{c}-0.033^{*} \\
(0.017)\end{array}$ & $\begin{array}{r}-0.043 * * \\
(0.018)\end{array}$ & $\begin{array}{c}-0.025^{*} \\
(0.013)\end{array}$ \\
\hline Population growth & $\begin{array}{r}0.078 \\
(0.705)\end{array}$ & $\begin{array}{r}0.130 \\
(0.701)\end{array}$ & $\begin{array}{r}-0.576 \\
(0.627)\end{array}$ & $\begin{array}{r}0.142 \\
(0.696)\end{array}$ & $\begin{array}{r}0.044 \\
(0.624)\end{array}$ \\
\hline Agglomeration & $\begin{array}{r}0.172 * * * \\
(0.047)\end{array}$ & $\begin{array}{r}0.191 * * * \\
(0.058)\end{array}$ & $\begin{array}{r}0.155^{* * * *} \\
(0.045)\end{array}$ & $\begin{array}{r}0.138 * * \\
(0.054)\end{array}$ & $\begin{array}{r}0.162 * * * \\
(0.046)\end{array}$ \\
\hline Level of accessibility index & $\begin{array}{r}-0.065^{* *} \\
(0.030)\end{array}$ & $\begin{array}{r}-0.125 * * * \\
(0.034)\end{array}$ & $\begin{array}{r}-0.024 \\
(0.042)\end{array}$ & $\begin{array}{r}-0.067 * \\
(0.035)\end{array}$ & $\begin{array}{r}-0.100 * * * \\
(0.031)\end{array}$ \\
\hline Change of accessibility index & $\begin{array}{r}-0.438 * * * \\
(0.100)\end{array}$ & $\begin{array}{c}-0.229^{*} \\
(0.128)\end{array}$ & $\begin{array}{r}-0.150 \\
(0.126)\end{array}$ & $\begin{array}{r}-0.437 * * * \\
(0.107)\end{array}$ & $\begin{array}{r}-0.296 * * * \\
(0.087)\end{array}$ \\
\hline Level of human capital \& innovation index & $\begin{array}{r}0.095 * * * \\
(0.032)\end{array}$ & $\begin{array}{l}0.069 * \\
(0.037)\end{array}$ & $\begin{array}{r}0.087 * * \\
(0.034)\end{array}$ & $\begin{array}{r}0.095^{* *} \\
(0.034)\end{array}$ & $\begin{array}{r}0.074 * * \\
(0.033)\end{array}$ \\
\hline Change of human capital \& innovation index & $\begin{array}{r}-0.020 \\
(0.037)\end{array}$ & $\begin{array}{r}-0.009 \\
(0.042)\end{array}$ & $\begin{array}{r}-0.017 \\
(0.039)\end{array}$ & $\begin{array}{r}-0.014 \\
(0.041)\end{array}$ & $\begin{array}{r}-0.011 \\
(0.041)\end{array}$ \\
\hline Level of institutional quality (QoG) & $\begin{array}{r}-1.117 * * * \\
(0.193)\end{array}$ & & & & \\
\hline Change of institutional quality (QoG) & $\begin{array}{r}0.792 * * * \\
(0.171)\end{array}$ & & & & \\
\hline \multicolumn{6}{|l|}{ Institutional index components } \\
\hline Level of corruption index & & $\begin{array}{r}0.013 \\
(0.116)\end{array}$ & & & \\
\hline Change of corruption index & & $\begin{array}{r}0.281 * * * \\
(0.090)\end{array}$ & & & \\
\hline Level of rule of law index & & & $\begin{array}{r}-0.792 * * * \\
(0.184)\end{array}$ & & \\
\hline Change of rule of law index & & & $\begin{array}{r}-0.103 \\
(0.073)\end{array}$ & & \\
\hline Level of government effectiveness & & & & $\begin{array}{r}-0.621 * * * \\
(0.16)\end{array}$ & \\
\hline Change of government effectiveness & & & & $\begin{array}{r}0.231 * * \\
(0.096)\end{array}$ & \\
\hline Level of government accountability & & & & & $\begin{array}{l}-0.233 \\
(0.147)\end{array}$ \\
\hline Change of government accountability & & & & & $\begin{array}{r}0.795 * * * \\
(0.117)\end{array}$ \\
\hline Constant & $\begin{array}{r}3.124 * * * \\
(0.686)\end{array}$ & $\begin{array}{r}1.222 * * \\
(0.556)\end{array}$ & $\begin{array}{r}2.603 * * * \\
(0.680)\end{array}$ & $\begin{array}{r}2.778 * * * \\
(0.791)\end{array}$ & $\begin{array}{r}1.401 * * * \\
(0.466)\end{array}$ \\
\hline Observations & 347 & 347 & 347 & 347 & 347 \\
\hline Number of regions & 27 & 27 & 27 & 27 & 27 \\
\hline Time FE & YES & YES & YES & YES & YES \\
\hline $\mathrm{R}^{2}$ within & 0.589 & 0.562 & 0.603 & 0.578 & 0.600 \\
\hline $\mathrm{R}^{2}$ between & 0.014 & 0.044 & 0.002 & 0.024 & 0.017 \\
\hline $\mathrm{R}^{2}$ overall & 0.015 & 0.049 & 0.0280 & 0.031 & 0.054 \\
\hline
\end{tabular}

Notes: $* * *, * * *$ illustrate significance at $10 \%, 5 \%$, and $1 \%$, respectively. The standard errors are listed in parentheses. Investment is proxied by regional gross fixed capital formation as a percentage of GDP. All independent variables are included with a five year lag. Natural logarithms have been taken for most regressors apart from the population growth variable. All regressions include constant time dummies.

The analysis is conducted for 27 of the officially designated 'low growth regions'. Melilla in Spain is excluded from the analysis. 
Hence, the results indicate that in the low growth regions of Europe government quality is a powerful catalyst of economic growth, as well as a mechanism to stem economic decline. Unfavourable government quality conditions have not deterred growth, while progress in government quality has been central in determining which regions have been able to surf better the boom and bust cycle of the last few years.

\subsubsection{Low income regions}

Do the low income regions of Bulgaria, Hungary, Poland, and Romania behave in the same way? Table 3 reproduces the same analysis for the 19 officially designated low income regions. The results differ considerably from those of the low growth regions group. The only constant is the presence of convergence within the group. In the case of low income regions, economic performance in recent years has been boosted by the sorts of interventions which have been at the heart of European Cohesion Policy. Regions with a better endowment of human capital and innovation capacity and those which have witnessed a larger relative progress in accessibility have performed considerably better than those where these conditions were missing. 
Table 3. The drivers of growth - levels and change - in low income regions of the EU (1999-2013). Fixed effects estimation.

\begin{tabular}{|c|c|c|c|c|c|}
\hline \multirow[b]{2}{*}{ Variables } & \multicolumn{5}{|c|}{ Fixed effects analysis } \\
\hline & $(1)$ & $(2)$ & (3) & $(4)$ & $(5)$ \\
\hline Initial GDP per capita & $\begin{array}{r}-0.265 * * * \\
(0.044)\end{array}$ & $\begin{array}{r}-0.287 * * * \\
(0.042)\end{array}$ & $\begin{array}{r}-0.312 * * * \\
(0.050)\end{array}$ & $\begin{array}{r}-0.265 * * * \\
(0.049)\end{array}$ & $\begin{array}{r}-0.273 * * * \\
(0.043)\end{array}$ \\
\hline Investment & $\begin{array}{r}0.006 \\
(0.013)\end{array}$ & $\begin{array}{r}-0.003 \\
(0.014)\end{array}$ & $\begin{array}{r}0.012 \\
(0.011)\end{array}$ & $\begin{array}{r}-0.006 \\
(0.013)\end{array}$ & $\begin{array}{r}0.005 \\
(0.010)\end{array}$ \\
\hline Population growth & $\begin{array}{r}0.166 \\
(0.337)\end{array}$ & $\begin{array}{r}0.162 \\
(0.355)\end{array}$ & $\begin{array}{r}0.204 \\
(0.288)\end{array}$ & $\begin{array}{l}0.0683 \\
(0.371)\end{array}$ & $\begin{array}{r}0.610 * * \\
(0.264)\end{array}$ \\
\hline Agglomeration & $\begin{array}{c}0.211^{* *} \\
(0.0902)\end{array}$ & $\begin{array}{r}0.307 * * \\
(0.111)\end{array}$ & $\begin{array}{c}0.195^{*} \\
(0.100)\end{array}$ & $\begin{array}{r}0.299 * * \\
(0.116)\end{array}$ & $\begin{array}{r}0.158 \\
(0.135)\end{array}$ \\
\hline Level of accessibility index & $\begin{array}{r}-0.602 * * * \\
(0.124)\end{array}$ & $\begin{array}{r}-0.600 * * * \\
(0.133)\end{array}$ & $\begin{array}{r}-0.613 * * * \\
(0.127)\end{array}$ & $\begin{array}{r}-0.560 * * * \\
(0.115)\end{array}$ & $\begin{array}{r}-0.581 * * * \\
(0.115)\end{array}$ \\
\hline Change of accessibility index & $\begin{array}{r}0.746 * * * \\
\quad(0.238)\end{array}$ & $\begin{array}{r}0.808 * * * \\
(0.246)\end{array}$ & $\begin{array}{c}0.673 * * \\
(0.268)\end{array}$ & $\begin{array}{r}0.765 * * * \\
(0.223)\end{array}$ & $\begin{array}{r}0.706 * * * \\
(0.224)\end{array}$ \\
\hline Level of human capital \& innovation index & $\begin{array}{r}0.088 * * \\
(0.034)\end{array}$ & $\begin{array}{c}0.097 * * \\
(0.036)\end{array}$ & $\begin{array}{r}0.073 * * \\
(0.032)\end{array}$ & $\begin{array}{r}0.099 * * * \\
(0.034)\end{array}$ & $\begin{array}{r}0.0740 * * \\
(0.031)\end{array}$ \\
\hline Change of human capital \& innovation index & $\begin{array}{r}-0.038 \\
(0.041)\end{array}$ & $\begin{array}{r}-0.045 \\
(0.042)\end{array}$ & $\begin{array}{r}-0.040 \\
(0.047)\end{array}$ & $\begin{array}{r}-0.043 \\
(0.040)\end{array}$ & $\begin{array}{r}-0.010 \\
(0.043)\end{array}$ \\
\hline Level of institutional quality (QoG) & $\begin{array}{c}-0.387 * \\
(0.211)\end{array}$ & & & & \\
\hline Change of institutional quality (QoG) & $\begin{array}{c}-0.129 \\
(0.311)\end{array}$ & & & & \\
\hline Institutional index components & & & & & \\
\hline Level of corruption index & & $\begin{array}{c}-0.109 \\
(0.175)\end{array}$ & & & \\
\hline Change of corruption index & & $\begin{array}{r}0.038 \\
(0.185)\end{array}$ & & & \\
\hline Level of rule of law index & & & $\begin{array}{r}-0.571 * * * \\
(0.169)\end{array}$ & & \\
\hline Change of rule of law index & & & $\begin{array}{r}0.065 \\
(0.291)\end{array}$ & & \\
\hline Level of government effectiveness & & & & $\begin{array}{r}-0.185 \\
(0.223)\end{array}$ & \\
\hline Change of government effectiveness & & & & $\begin{array}{l}-0.135 \\
(0.165)\end{array}$ & \\
\hline Level of government accountability & & & & & $\begin{array}{r}-0.426 * * * \\
(0.142)\end{array}$ \\
\hline Change of government accountability & & & & & $\begin{array}{l}0.0587 \\
(0.182)\end{array}$ \\
\hline Constant & $\begin{array}{r}8.585 * * * \\
(2.054)\end{array}$ & $\begin{array}{r}6.951 * * * \\
(1.919) \\
\end{array}$ & $\begin{array}{r}9.806^{* * * *} \\
(1.879)\end{array}$ & $\begin{array}{r}6.449 * * * \\
(2.055)\end{array}$ & $\begin{array}{r}9.145 * * * \\
(2.314)\end{array}$ \\
\hline Observations & 244 & 244 & 244 & 244 & 244 \\
\hline Number of regions & 19 & 19 & 19 & 19 & 19 \\
\hline Time FE & YES & YES & YES & YES & YES \\
\hline $\mathrm{R}^{2}$ within & 0.637 & 0.629 & 0.651 & 0.631 & 0.650 \\
\hline $\mathrm{R}^{2}$ between & 0.102 & 0.135 & 0.108 & 0.144 & 0.156 \\
\hline $\mathrm{R}^{2}$ overall & 0.0876 & 0.108 & 0.0755 & 0.113 & 0.0966 \\
\hline
\end{tabular}

Notes: $* * *, * * *$ illustrate significance at $10 \%, 5 \%$, and $1 \%$, respectively, respectively. The standard errors are listed in parentheses.

Investment is proxied by regional gross fixed capital formation as a percentage of GDP. All independent variables are included with a five year lag. Natural logarithms have been taken for most regressors apart from the population growth variable. All regressions include constant time dummies. 
In contrast, none of the quality of government variables displays a positive and significant relationship with economic growth during the period of analysis. Only for the case of the levels of rule of law and government accountability a significant connection to economic performance emerges. The sign of the coefficient is, nevertheless, negative (Table 3, regressions 3 and 5). Hence, while for the low growth regions of Southern Europe economic performance has been strongly related to change in government quality, growth in the low income regions of Central and Eastern Europe is much more dependent on the traditional factors, according to growth theories, behind economic change. It can therefore be said that, while in low income regions investing in redressing the imbalance in endowments with the rest of Europe makes sense from an economic point of view, in the low growth regions - which have benefited from this type of investment throughout the life of the Structural and Cohesion funds and where, as a consequence, the gap in basic endowments is considerably lower - the capacity to generate growth and weather economic crises has become much more dependent on improving the institutional conditions which act as a barrier for economic development.

\section{Government quality and place-sensitive policies for lagging regions in Europe.}

What are the implications for policy that can be extracted from the analysis? Although measuring government quality is always controversial and leads to some caution when interpreting the results, a number of important policy consequences can be derived.

\subsection{Institutions matter}

The first implication of the analysis is that quality of government matters for regional development in Europe. Over a period which includes economic boom, as well as the greatest and most prolonged economic depression Europe has experienced since the 1930s, government quality has been among the most consistent predictors of economic growth and resilience. This contrasts with more mixed results in the sway of education and innovation and with what is a lack of connection - when not an outright negative one - between levels and improvements in accessibility, on the one hand, and economic performance, on the other, for the whole of Europe. This implies that, in order for 
economic development at a regional level in Europe to take hold, measures to improve government quality need to become an integral part of any development strategy.

\subsection{Relative improvements in quality of government are a powerful driver of development}

In particular, relative improvements in government quality have been fundamental for economic growth. Whereas poor government quality has not represented a barrier for development - indeed, regions that are characterised by weak government institutions have, once other factors are controlled for, converged towards the EU average - regions that have managed to reduce corruption levels and have made progress in government effectiveness, transparency and accountability have also had a better economic trajectory.

Consequently, improving government efficiency by either addressing widespread corruption or introducing measures aimed at making government decisions more efficient and transparent is as important a requisite for regional development in Europe, as conducting more traditional 'hard' types of regional development investments. Overall, the implementation of government efficiency-enhancing measures and the fight against corruption can lead to significant progress in the efficiency of public policies while, at the same time, reducing wastage in the overall use of scarce public resources (Afonso and Fernandes, 2006). But, as noted by Tanzi (1998: 587), any strategy in this respect has to start by an awareness and an acknowledgement that these factors are a problem and a significant barrier for public policies to take hold and for economic development intervention to take off.

\subsection{One-size-fits-all policies for lagging regions are not the solution}

Acknowledging the importance of quality of government and implementing the necessary steps to improve government quality, however, does not necessarily mean that the same policies targeting institutions have to be adopted across lagging regions of the EU. The results of the analysis make clear that what has worked in certain lagging regions, does not necessarily work in others. Mimetically reproducing the same style of policy across the less developed regions of Europe has not yielded the expected results 
in the past and is unlikely to do so in future. Consequently, different development strategies are needed in different places and at different stages of development. The empirical analysis has shown that, at lower levels of development, such as those found in the low income regions of Central and Eastern Europe, the factors behind economic growth in recent years differ from those at higher levels of development and, more strikingly, from those of other lagging regions in Southern Europe. At lower levels of development, regional economic growth is driven by a good endowment of human capital and innovation, as well as by improvements in accessibility through investment in transport infrastructure. This implies that the traditional factors highlighted by the neoclassical and endogenous growth theories still play a fundamental part in driving economic performance in these areas.

As the level of initial development increases, regions hit a middle-income trap (Iammarino et al., 2018) and the influence of more traditional growth factors wanes. Hence, in the low growth regions of Southern Europe government quality becomes more relevant in determining which territories are and remain dynamic and which are not.

Consequently, the story emerging is one in which development strategies need to be specifically tailored to the conditions of every territory - that is, the implementation of place-sensitive policies - which will, to a great extent, depend on the stage of development in which any given European region finds itself. Therefore, while investments aimed at improving physical accessibility may play an important role in the early stages of implementation of a development strategy in the most lagging regions of Europe, the returns of such investments are bound to become less evident - and in many cases represent a waste of scarce public resources - in those areas that have already devoted substantial funds to the improvement of their transportation network through the Structural and Investment Funds, unless accompanied by significant progress in government quality (Crescenzi et al., 2016).

\subsection{Quality of government change as essential for low growth regions}

The analysis has evidenced that low government capacity in lagging regions of Europe does not necessarily represent a strong handicap for future development. Lack of 
improvement in government quality, by contrast, does. Low growth regions which have failed to improve government quality or have failed to reduce corruption, have been incapable of making the most of cohesion policy intervention and, as a consequence, have also grown less and been more exposed to the negative consequences of the crisis. These results corroborate Charron et al.'s (2014a: 81) claim that failure to address these institutional malfunctions condemns regions "to remain stuck in low growth and low QoG equilibrium, while the regional government remains to some degree sheltered from the financial consequences of low QoG through continuing support from the EU'. A sustained effort in order to address barriers in terms of government effectiveness, corruption, and deficient voice and accountability is therefore needed if the low growth regions are to experience both sustainable levels of development and greater convergence towards the rest of the EU.

\subsection{Addressing basic endowments shortages in low income regions}

In contrast, in the low income regions of Europe more traditional factors, such as a good human capital and innovation endowment and investments targeting improved accessibility are proving their worth as catalysts for growth. In these areas of Europe, strategic investments in infrastructure, in general, and in transport infrastructure, in particular, are likely to continue to contribute to economic development for some time. With still considerable deficits in basic infrastructure, improving accessibility in low income regions becomes a precondition for economic development. Tackling the infrastructure deficit thus needs to feature prominently in the early stages of the strategy. However, it has to be noted that the returns of improvements in accessibility are likely to diminish as accessibility constraints become less important. Consequently, any sort of infrastructure investment needs to be limited in time, respond to clear criteria of need and development potential, and be matched by similar efforts aimed at the enhancement of human capital and at tackling institutional bottlenecks.

\section{Conclusion: moving to the next level}

The analysis developed in this paper has stressed that for most lagging regions in Europe moving to the next level in economic development terms will not be easy unless 
carefully tailored development strategies are set up paying special attention to the specific conditions of each region. If development strategies are to be both capable of successfully addressing short-term problems, as well as of putting European lagging regions on a sustainable development track in the medium- to long-term, decisionmakers in every European region, nation as well as in Brussels will have to collaborate and to tread carefully in crafting development strategies that juggle the traditional investments aimed at improving infrastructure, human resources, and innovation with a greater focus on institutional issues, such as local government quality as a way to overcome the barriers to development that lagging regions face.

The policy lessons that emerge from the analysis point towards the need to carefully put together integrated and balanced development strategies in any development policy interventions. Development strategies would require encompassing an adequate mix of actions aimed at redressing regional infrastructure deficits, together with the active improvement of human resources and employment structures, and the upgrading of the institutional environment. The mix of all these interventions will vary from place to place, depending on initial conditions and levels of development. The timing of each action is also crucial. Invest too early, for too long, or too much on one of these development axes and the risk of ending up with a strategy that yields scarce returns is high. Under these circumstances institutional conditions are likely to become a more important and visible barrier to development. Comprehensive and well-timed placesensitive development strategies are needed not only address some of the basic problems of lagging regions in Europe, but also to enhance their capacity - and, as a consequence, that of Europe as a whole - to adopt new technologies, retain and attract talent, generate and simulate new investment, and, last but not least, make the most of the economic potential across the whole of Europe. Such an approach is also bound to set the bases for a more sustainable growth in lagging regions of Europe. 


\section{Acknowledgements}

The authors are grateful to the special issue editors, the managing editor and the three reviewers for their insightful suggestions and comments made during the refereeing process. Özge Öner was particularly helpful in challenging some of the points made in the econometric analysis in past iterations. Earlier versions of the paper benefited from the feedback received by participants at presentations in Athens, Beijing, Boston, Brussels, Frankfurt, Groningen, Jena, L’Aquila, Madrid, Milan, Oxford, Porto, Rome, Santiago de Compostela, Split, Stavanger, Stockholm, Tokyo, Turin, Utrecht and Warsaw. The content of this paper does not reflect the official opinion of the European Union. Responsibility for the information and views expressed therein lies entirely with the authors. 


\section{References}

Akçomak, I. S., \& Ter Weel, B. (2009). Social capital, innovation and growth: Evidence from Europe. European Economic Review, 53(5), 544-567.

Afonso, A., \& Fernandes, S. (2006). Measuring local government spending efficiency: evidence for the Lisbon region. Regional Studies, 40(1), 39-53.

Annoni, P. \& Dijkstra, L. (2013). EU regional competitiveness index (RCI 2013). Publications Office.

Becker, S., Egger, P., \& von Ehrlich, M. (2010). Going NUTS: The effect of EU Structural Funds on regional performance, Journal of Public Economics, 94, 578-590.

Beugelsdijk, S., \& Van Schaik, T. (2005). Differences in social capital between 54 Western European regions. Regional Studies, 39(8), 1053-1064.

Charron, N., Dijkstra, L., \& Lapuente, V. (2014a). Regional governance matters: quality of government within European Union member states. Regional Studies, 48(1), 68-90.

Charron, N., Dijkstra, L., \& Lapuente, V. (2014b). Mapping the Regional Divide in Europe: A Measure for Assessing Quality of Government in 206 European Regions. Social Indicators Research, 122(2), 315-346.

Charron, N., \& Lapuente, V. (2013). Why do some regions in Europe have a higher quality of government?. The Journal of Politics, 75(3), 567-582.

Charron, N., Lapuente, V., \& Rothstein, B. (2011). Measuring Quality of Government and Sub-national Variation, Report for the EU Commission of Regional Development European Commission Directorate-General Regional Policy Directorate Policy Development.

Charron, N., Lapuente, V. \& Rothstein, B. (2013). Quality of government and corruption from a European perspective: a comparative study on the quality of government in EU regions. Edward Elgar Publishing. 250pp.

Crescenzi, R., Di Cataldo, M., \& Rodríguez-Pose, A. (2016). Government quality and the economic returns of transport infrastructure investment in European regions. Journal of Regional Science, 56(4), 555-582.

Crescenzi, R., \& Rodríguez-Pose, A. (2012). Infrastructure and regional growth in the European Union. Papers in Regional Science, 91(3), 487-513.

Cuadrado-Roura, J.R. Martin, R., \& Rodríguez Pose, A. (2016). The economic crisis in Europe: Urban and regional consequences. Cambridge Journal of Regions, Economy and Society, 9(1), 3-11.

European Commission (2014). Investment for jobs and growth: Promoting development and good governance in EU regions and cities: Sixth report on economic and social cohesion. Brussels: Publications Office of the European Commission. 
Halkos, G. E., Sundström, A., \& Tzeremes, N. G. (2015). Regional environmental performance and governance quality: a nonparametric analysis. Environmental Economics and Policy Studies, 17(4), 621-644.

Iammarino, S., Rodríguez-Pose, A., \& Storper, M. (2018). Regional inequality in Europe: evidence, theory and policy implications. Journal of Economic Geography forthcoming.

Kaufmann, D., Kraay, A., \& Mastruzzi, M. (2009). Governance Matters VIII: Aggregate and Individual Governance Indicators, 1996-2008, World Bank Policy Research Working Paper No. 4978.

Ketterer, T. D. \& Rodríguez-Pose, A. (2015). Local quality of government and voting with one's feet. Annals of Regional Science, 55(2-3), 501-532.

Lucas, R. E. (1988). On the mechanics of economic development. Journal of Monetary Economics, 22(1), 3-42.

Mankiw, N., Romer, P., \& Weil, D. (1992). A contribution to the empirics of economic growth. Quarterly Journal of Economics 107, 407-437.

Pellegrini, G., Terribile, F., Tarola, O., Muccigrosso, T., \& Busillo, F. (2013). Measuring the effects of European Regional Policy on economic growth: A regression discontinuity approach. Papers in Regional Science, 92(1), 217-233.

Nistotskaya, M., Charron, N., \& Lapuente, V. (2015) The wealth of regions: quality of government and SMEs in 172 European regions. Environment and Planning C: Government and Policy, 33(5), 1125-1155.

Rodríguez-Pose, A. (2013). Do institutions matter for regional development? Regional Studies, 47(7), 1034-1047.

Rodríguez-Pose, A. (2018). The revenge of the places that don't matter (and what to do about it). Cambridge Journal of Regions, Economy and Society, 11(1), 189-209.

Rodríguez-Pose, A. and Di Cataldo, M. (2015) Quality of government and innovative performance in the regions of Europe. Journal of Economic Geography, 15(4), 673-706.

Rodríguez-Pose, A., \& Garcilazo, E. (2015). Quality of government and the returns of investment: Examining the impact of cohesion expenditure in European regions. Regional Studies, 49(8), 1274-1290.

Romer, P.M. (1986). Increasing returns and long-run growth, Journal of Political Economy, 94(5), 1002-37.

Roodman, D. (2009). How to do xtabond2: an introduction to difference and system GMM in Stata, Stata Journal, 9(1), 86-136. 
Solow, R. (1956) A contribution to the theory of economic growth. Quarterly Journal of Economics, 70(1), 65-94.

Sundström, A., \& Wängnerud, L. (2016). Corruption as an obstacle to women's political representation: Evidence from local councils in 18 European countries. Party Politics, 22(3), 354-369.

Swan, T. (1956). Economic growth and capital accumulation. Economic Record, 32, 334-361.

Tanzi, V. (1998). Corruption around the world: Causes, consequences, scope, and cures. IMF Staff Papers, 45(4), 559-594. 


\section{ANNEX}

Table A1. Description of Variables

\begin{tabular}{|c|c|c|}
\hline Variable & Exact definition & Data source \\
\hline Dependent variable & Annual growth rate of regional GDP (PPS) per capita & $\begin{array}{l}\text { Eurostat' Regio } \\
\text { Database }\end{array}$ \\
\hline \multicolumn{3}{|l|}{ Investment and Infrastructure } \\
\hline Gross fixed capital formation & $\begin{array}{l}\text { Gross fixed capital formation in per cent of nominal } \\
\text { GDP }\end{array}$ & $\begin{array}{l}\text { Eurostat' Regio } \\
\text { Database }\end{array}$ \\
\hline Accessibility by road & $\begin{array}{l}\text { Road network data measuring potential road } \\
\text { accessibility as the inverse time-distance weighted } \\
\text { population }\end{array}$ & $\begin{array}{l}\text { Klaus Spiekermann and } \\
\text { European Commission }\end{array}$ \\
\hline Accessibility by air & $\begin{array}{l}\text { Total number of air transport passengers in thousand } \\
\text { standardized by regional population size }\end{array}$ & $\begin{array}{l}\text { Eurostat' Regio } \\
\text { Database }\end{array}$ \\
\hline \multicolumn{3}{|c|}{ Human capital, innovation and demography } \\
\hline $\begin{array}{l}\text { Tertiary education } \\
\text { employment }\end{array}$ & $\begin{array}{l}\text { Percentage of employed people (aged 25-64) with } \\
\text { completed higher education (ISCED-97 levels } 5 \text { and 6). }\end{array}$ & $\begin{array}{l}\text { Eurostat' Regio } \\
\text { Database }\end{array}$ \\
\hline Life-long-learning ratio & $\begin{array}{l}\text { Participation of adults aged } 25-64 \text { in education and } \\
\text { training in per cent. }\end{array}$ & $\begin{array}{l}\text { Eurostat' Regio } \\
\text { Database }\end{array}$ \\
\hline Patent applications & $\begin{array}{l}\text { Number of patent applications per million of } \\
\text { inhabitants }\end{array}$ & $\begin{array}{l}\text { Eurostat' Regio } \\
\text { Database }\end{array}$ \\
\hline Total R\&D expenditure & $\begin{array}{l}\text { Total R\&D expenditure (in all sectors) in per cent of } \\
\text { GDP }\end{array}$ & $\begin{array}{l}\text { Eurostat' Regio } \\
\text { Database }\end{array}$ \\
\hline Population growth rate & Annual growth rate of the total regional population & $\begin{array}{l}\text { Eurostat' Regio } \\
\text { Database }\end{array}$ \\
\hline Agglomeration & Average population living within a $25 \mathrm{~km}$ radius & European Commission \\
\hline
\end{tabular}

\section{Regional institutional measures}

Control of corruption

Rule of law

Government effectiveness

Government accountability

Quality of Government Index
Index evaluating corruption in the public school and health care system, and other public services Constructed index measuring residents' perception of the objectivity and confidence in the police and in regional law enforcement

Index measure identifying the quality and impartiality of regional health care and education services Composite index analysing the perceived honesty of elections and the effectiveness of the media as a watchdog for public sector corruption

Regional quality of government index constructed combining all the previous four indicators
Charron et al. (2014a)

Charron et al. (2014a)

Charron et al. (2014a)

Charron et al. (2014a)

Charron et al. (2014a) 
Table A2a. Descriptive statistics

\begin{tabular}{lrrrrr}
\hline Variable & Obs & Mean & Std.Dev. & Min & Max \\
\hline Annual growth rate of GDP per & 3544 & .03 & .046 & -.169 & .237 \\
capita & & & & \\
GDP per capita & 3798 & 22000.2 & 9070.748 & 3400 & 86400 \\
Gross fixed capital formation & 3645 & .208 & .161 & -.105 & 4.754 \\
Population growth rate & 3556 & .003 & .007 & -.052 & .045 \\
Agglomeration & 3765 & 698000 & 910000 & 18807.7 & 8060000 \\
Accessibility by air & 3810 & .002 & .003 & 0 & .032 \\
Accessibility by road & 3765 & 2840000 & 1970000 & 79465.95 & 8860000 \\
Tertiary education employment & 3748 & 24.669 & 8.997 & 6.2 & 60.2 \\
Life-long-learning & 3810 & 8.627 & 7.044 & .13 & 33.71 \\
Total R\&D expenditure & 3466 & 1.329 & 1.227 & .02 & 13.73 \\
Patent applications & 3810 & 83.247 & 110.568 & 0 & 996.579 \\
Quality of Government Index & 3810 & 10.228 & .967 & 6.706 & 11.623 \\
Control of corruption & 3810 & 10.227 & .936 & 6.62 & 11.8 \\
Rule of law & 3810 & 10.223 & .951 & 6.33 & 13.362 \\
Government effectiveness & 3810 & 10.215 & 1.088 & 6.518 & 12.02 \\
Government accountability & 3810 & 10.182 & .946 & 2.991 & 13.109 \\
\hline
\end{tabular}


Table A2b. Correlation matrix

\begin{tabular}{|c|c|c|c|c|c|c|c|c|c|c|c|c|c|c|c|c|}
\hline Variables & $(1)$ & $(2)$ & (3) & (4) & $(5)$ & (6) & (7) & $(8)$ & (9) & $(10)$ & $(11)$ & (12) & (13) & (14) & (15) & (16) \\
\hline (1) Annual growth rate of GDP per capita & 1.000 & & & & & & & & & & & & & & & \\
\hline (2) GDP per capita & -0.128 & 1.000 & & & & & & & & & & & & & & \\
\hline (3) Gross fixed capital formation & 0.053 & -0.078 & 1.000 & & & & & & & & & & & & & \\
\hline (4) Population growth rate & -0.202 & 0.391 & -0.013 & 1.000 & & & & & & & & & & & & \\
\hline (5) Agglomeration & -0.035 & 0.445 & -0.077 & 0.148 & 1.000 & & & & & & & & & & & \\
\hline (6) Accessibility by air & -0.103 & 0.259 & -0.013 & 0.348 & 0.236 & 1.000 & & & & & & & & & & \\
\hline (7) Accessibility by road & -0.089 & 0.553 & -0.125 & 0.128 & 0.594 & 0.016 & 1.000 & & & & & & & & & \\
\hline (8) Tertiary education employment & -0.089 & 0.478 & 0.016 & 0.175 & 0.430 & 0.171 & 0.406 & 1.000 & & & & & & & & \\
\hline (9) Life-long-learning & -0.184 & 0.423 & -0.095 & 0.189 & 0.207 & 0.118 & 0.216 & 0.463 & 1.000 & & & & & & & \\
\hline (10) Total R\&D expenditure & -0.049 & 0.454 & -0.057 & 0.167 & 0.285 & 0.093 & 0.420 & 0.471 & 0.398 & 1.000 & & & & & & \\
\hline (11) Patent applications & -0.051 & 0.505 & -0.088 & 0.116 & 0.206 & 0.066 & 0.548 & 0.307 & 0.258 & 0.650 & 1.000 & & & & & \\
\hline (12) Quality of Government Index & -0.144 & 0.535 & -0.058 & 0.283 & 0.091 & 0.096 & 0.403 & 0.411 & 0.526 & 0.433 & 0.476 & 1.000 & & & & \\
\hline (13) Control of corruption & -0.152 & 0.539 & -0.077 & 0.261 & 0.106 & 0.101 & 0.425 & 0.406 & 0.545 & 0.448 & 0.547 & 0.957 & 1.000 & & & \\
\hline (14) Rule of law & -0.151 & 0.505 & -0.062 & 0.267 & 0.075 & 0.114 & 0.355 & 0.367 & 0.506 & 0.416 & 0.457 & 0.970 & 0.920 & 1.000 & & \\
\hline (15) Government effectiveness & -0.113 & 0.489 & -0.034 & 0.279 & 0.106 & 0.086 & 0.380 & 0.441 & 0.483 & 0.412 & 0.398 & 0.959 & 0.868 & 0.911 & 1.000 & \\
\hline (16) Government accountability & -0.167 & 0.554 & -0.049 & 0.305 & 0.096 & 0.081 & 0.415 & 0.390 & 0.492 & 0.398 & 0.436 & 0.899 & 0.856 & 0.863 & 0.804 & 1.000 \\
\hline
\end{tabular}


Table A3. Correlation and eigenvector analysis of the principal component analysis

\section{ACCESSIBILITY INDEX}

Principal components/correlation

Number of obs $=3765$

Number of comp. $=2$

Trace $=2$

Rotation: $($ unrotated $=$ principal $)$

Rho $\quad=1.0000$

\begin{tabular}{lcrrr}
\hline Component & Eigenvalue & Difference & Proportion & Cumulative \\
\hline Comp1 & 1.04406 & .0881158 & 0.5220 & 0.5220 \\
Comp2 & .955942 &. & 0.4780 & 1.0000 \\
\hline \multicolumn{2}{l}{ Principal components (eigenvectors) } & & & \\
\multicolumn{2}{l}{ Variable } & Comp1 & Comp2 & Unexplained \\
\hline Accessibility by air & 0.7071 & 0.7071 & 0 \\
Accessibility by road & 0.7071 & -0.7071 & 0 \\
\hline
\end{tabular}

\section{HUMAN CAPITAL \& INNOVATION INDEX}

Principal components/correlation

Rotation: $($ unrotated $=$ principal $)$

$\begin{array}{lcc}\text { Number of obs } & = & 3404 \\ \text { Number of comp. } & 4 \\ \text { Trace } & = & 4 \\ \text { Rho } & = & 1.0000\end{array}$

\begin{tabular}{lrrrr}
\hline Component & \multicolumn{1}{c}{ Eigenvalue } & Difference & \multicolumn{1}{c}{ Proportion } & \multicolumn{1}{c}{ Cumulative } \\
\hline Comp1 & 2.31213 & 1.47238 & 0.5780 & 0.5780 \\
Comp2 & .839757 & .30852 & 0.2099 & 0.7880 \\
Comp3 & .531237 & .214366 & 0.1328 & 0.9208 \\
Comp4 & .316871 &. & 0.0792 & 1.0000 \\
\hline
\end{tabular}

Principal components (eigenvectors)

\begin{tabular}{lccccc}
\hline Variable & Comp1 & Comp2 & Comp3 & Comp4 & Unexplained \\
\hline Tertiary education employment & 0.4858 & 0.4400 & -0.7199 & 0.2284 & 0 \\
Life-long-learning ratio & 0.4556 & 0.5702 & 0.6795 & 0.0746 & 0 \\
Total R\&D expenditure & 0.5648 & -0.2976 & -0.0446 & -0.7684 & 0 \\
Patent applications & 0.4874 & -0.6267 & 0.1340 & 0.5931 & 0 \\
\hline
\end{tabular}


Table A4. The drivers of growth - levels and change - at a regional level in the EU (1999-2013). System-GMM analysis.

\begin{tabular}{|c|c|c|c|c|c|}
\hline \multirow[b]{2}{*}{ Variables } & \multicolumn{5}{|c|}{ System-GMM analysis } \\
\hline & $(1)$ & $(2)$ & (3) & (4) & $(5)$ \\
\hline Initial GDP per capita & $\begin{array}{r}-0.047 * * * \\
(0.008)\end{array}$ & $\begin{array}{r}-0.052 * * * \\
(0.008)\end{array}$ & $\begin{array}{r}-0.048 * * * \\
(0.007)\end{array}$ & $\begin{array}{r}-0.040 * * * \\
(0.007)\end{array}$ & $\begin{array}{r}-0.045^{* * *} \\
(0.007)\end{array}$ \\
\hline Investment & $\begin{array}{r}0.011 * * * \\
(0.004)\end{array}$ & $\begin{array}{r}0.011 * * * \\
(0.004)\end{array}$ & $\begin{array}{r}0.009^{* *} \\
(0.004)\end{array}$ & $\begin{array}{r}0.013 * * * \\
(0.004)\end{array}$ & $\begin{array}{r}0.011 * * * \\
(0.004)\end{array}$ \\
\hline Population growth & $\begin{array}{r}-0.248 \\
(0.217)\end{array}$ & $\begin{array}{r}-0.277 \\
(0.227)\end{array}$ & $\begin{array}{c}-0.400^{*} \\
(0.237)\end{array}$ & $\begin{array}{r}-0.348^{*} \\
(0.211)\end{array}$ & $\begin{array}{r}-0.314 \\
(0.216)\end{array}$ \\
\hline Agglomeration & $\begin{array}{r}0.013 * * * \\
(0.004)\end{array}$ & $\begin{array}{r}0.012 * * * \\
\quad(0.004)\end{array}$ & $\begin{array}{c}0.010 * * \\
(0.004)\end{array}$ & $\begin{array}{r}0.010 * * * \\
(0.004)\end{array}$ & $\begin{array}{r}0.012 * * * \\
(0.003)\end{array}$ \\
\hline Level of accessibility index & $\begin{array}{r}-0.005 \\
(0.004)\end{array}$ & $\begin{array}{r}-0.002 \\
(0.004)\end{array}$ & $\begin{array}{r}-0.0012 \\
(0.0041)\end{array}$ & $\begin{array}{r}-0.005 \\
(0.004)\end{array}$ & $\begin{array}{r}-0.005 \\
(0.004)\end{array}$ \\
\hline Change of accessibility index & $\begin{array}{r}-0.219 * * \\
(0.110)\end{array}$ & $\begin{array}{r}-0.165 \\
(0.112)\end{array}$ & $\begin{array}{c}-0.214^{*} \\
(0.118)\end{array}$ & $\begin{array}{r}-0.238 * * \\
(0.111)\end{array}$ & $\begin{array}{r}-0.218^{*} \\
(0.112)\end{array}$ \\
\hline Level of human capital \& innovation index & $\begin{array}{r}0.010 \\
(0.006)\end{array}$ & $\begin{array}{r}0.008 \\
(0.006)\end{array}$ & $\begin{array}{c}0.011^{*} \\
(0.006)\end{array}$ & $\begin{array}{r}0.016 * * * \\
(0.006)\end{array}$ & $\begin{array}{r}0.0150 * * * \\
(0.005)\end{array}$ \\
\hline Change of human capital \& innovation index & $\begin{array}{r}-0.070 * * * \\
(0.026)\end{array}$ & $\begin{array}{r}-0.050 * * \\
(0.024)\end{array}$ & $\begin{array}{r}-0.060 * * * \\
(0.020)\end{array}$ & $\begin{array}{r}-0.072 * * * \\
(0.022)\end{array}$ & $\begin{array}{r}-0.049 * * \\
(0.022)\end{array}$ \\
\hline Level of institutional quality (QoG) & $\begin{array}{r}0.043 \\
(0.035)\end{array}$ & & & & \\
\hline Change of institutional quality (QoG) & $\begin{array}{r}0.384 * * * \\
(0.133)\end{array}$ & & & & \\
\hline \multicolumn{6}{|l|}{ Institutional index components } \\
\hline Level of corruption index & & $\begin{array}{c}0.062 * \\
(0.036)\end{array}$ & & & \\
\hline Change of corruption index & & $\begin{array}{l}0.135 * \\
(0.072)\end{array}$ & & & \\
\hline Level of rule of law index & & & $\begin{array}{r}0.063 * * \\
(0.030)\end{array}$ & & \\
\hline Change of rule of law index & & & $\begin{array}{r}-0.331 * * * \\
(0.0997)\end{array}$ & & \\
\hline Level of government effectiveness & & & & $\begin{array}{r}0.007 \\
(0.026)\end{array}$ & \\
\hline Change of government effectiveness & & & & $\begin{array}{r}0.279 * * * \\
(0.053)\end{array}$ & \\
\hline Level of government accountability & & & & & $\begin{array}{r}0.018 \\
(0.026)\end{array}$ \\
\hline Change of government accountability & & & & & $\begin{array}{r}0.317 * * * \\
(0.068) \\
\end{array}$ \\
\hline Observations & 2,802 & 2,802 & 2,802 & 2,801 & 2,802 \\
\hline Number of NUTS-2 regions & 249 & 249 & 249 & 249 & 249 \\
\hline Number of instruments & 286 & 286 & 286 & 289 & 286 \\
\hline AR (2) test statistic (p-value) & 0.205 & 0.385 & 0.865 & 0.280 & 0.248 \\
\hline AR (3) test statistic (p-value) & 0.112 & 0.129 & 0.275 & 0.221 & 0.0585 \\
\hline Hansen Test (p-value) & 0.764 & 0.267 & 0.000 & 0.000 & 0.000 \\
\hline
\end{tabular}


